\title{
Design, synthesis, and evaluation of some novel N-benzothiazol-2-yl benzamide derivatives as allosteric activators of human glucokinase
}

\author{
Sandeep Arora, Ajmer Singh Grewal, Neelam Sharma, Kunal Arora, Ervon Dhalio, Sukhbir Singh* \\ Chitkara College of Pharmacy, Chitkara University, Punjab, India.
}

\author{
ARTICLE INFO \\ Received on: 30/10/2019 \\ Accepted on: 28/06/2020 \\ Available online: 25/02/2021 \\ Key words: \\ Benzamides, benzothiazole \\ derivatives, docking, \\ glucokinase, GK activators, \\ in silico, GK assay.
}

\begin{abstract}
Some newer benzamide analogues of N-benzothiazol-2-yl were prepared and assessed for human glucokinase (GK) activation accompanied by molecular docking investigations for predicting the bonding connections of the these derivatives with residues in the allosteric site of GK. Among the derivatives synthesized, 6 and 7 strongly increased the catalytic action of GK (GK activation fold about 2.0 compared to control) in vitro. The outcomes of in vitro assay were supported by the molecular docking investigations of these analogues with allosteric site residues of the GK protein. Derivatives investigated in the present study can afford few lead compounds for the discovery of harmless and strong allosteric GK activating compounds for the management of type 2 diabetes.
\end{abstract}

\section{INTRODUCTION}

Type 2 diabetes (T2D) is a life-long food metabolism ailment owing to decreased insulin action resulting in hyperglycemia and is prevalent among most of the patients suffering from diabetes (Bastaki, 2005; Kohei, 2010; Olokoba et al., 2012). Although ample types of oral antidiabetic agents are available to be used in the management of T2D, no individual antidiabetic agent is valuable in attaining persistent homeostasis of plasma sugar within usual physiological range in majority of the persons suffering from T2D. Owing to the above-mentioned points, nowadays doctors advise a combination of hypoglycemic agents in the initial phase of T2D treatment. Additionally, overdose of hypoglycemic drugs may possibly result in serious hypoglycemia triggering brutal adverse reactions, and patients generally require urgent medical treatment (Grewal et al., 2016b; Olokoba et al., 2012; Pal, 2009b). Nowadays, medicinal chemistry scientists are aiming at designing newer effective hypoglycemic agents having distinct mechanisms of action at the molecular level

Abstract of this article was presented at CUDC consortium and Summer School Conference at Chitkara University, India.

*Corresponding Author

Sukhbir Singh, Chitkara College of Pharmacy, Chitkara University,

Rajpura, India.E-mail: sukhbir.singh@chitkara.edu.in which could be used as a single drug with improved safety (Grewal et al., 2014, 2016a). Glucokinase (GK) is a cytoplasmic enzyme that is expressed predominantly in pancreatic $\beta$-cells and liver hepatocytes, and fastens the conversion of glucose to glucose-6phosphate with the help of adenosinetriphosphate (ATP) (Coghlan and Leighton, 2008; Pal, 2009a). In beta-cells of pancreas gland, GK regulates glucose-instigated discharge of insulin, and in liver hepatocytes of the liver, it commands the breakdown of sugars. GK acts as an emergent medication focus for treatment and management of T2D due to its key function in controlling sugar breakdown. Small molecule activators of human GK are the unique class of therapeutically useful agents that allosterically activate GK and illustrate their plasma sugar-lowering potential (Coghlan and Leighton, 2008; Grewal et al., 2014; Matschinsky et al., 2011; Perseghin, 2010). Several GK activators have been progressed into clinical trials (phase II), including AZD6370, AZD1656, MK-0941, Piragliatin, and AMG151; even though a strong decrease in blood sugar was observed, potential adverse reactions were reported, such as hypoglycemia and elevated levels of triglycerides. The literature survey revealed that most of the drug discovery and development research associated with allosteric activators of human GK were mainly focused on the substituted benzamide analogs probably owing to their corresponding alignment outline and bonding connections with the residues of 
allosteric location of GK (Grewal et al., 2014; Pal et al., 2009b). Some of the benzamide derivatives reported recently as potent GK activators are shown in Figure 1 along with their GK activity (Bowler et al., 2013; Charaya et al., 2018; Ericsson et al., 2012; Grewal et al., 2019a, 2019b; Lei et al., 2015; McKerrecher et al., 2018; Park et al., 2013, 2014; Pike et al., 2011; Sjostrand et al., 2013; Wang et al., 2017). Based on the above-mentioned facts, few newer N-benzothiazol-2-yl benzamide correspondents were proposed as potential activators of human GK.

\section{MATERIALS AND METHODS}

All the chemicals were acquired from reputed companies, including Spectrochem, Sisco Research Laboratories Pvt. Ltd. (SRL), S.D. Fine-Chem, Merck, Fisher Scientific, and SigmaAldrich etc., and employed without purification. Melting points of the synthesized molecules were determined using the uncorrected Veego Model of melting point apparatus melting point device. Culmination of reaction was checked employing silica Gel-G
Thin layer chromatography (TLC). IR spectra were obtained using "Shimadzu Fourier-transform infrared (FTIR) spectrophotometer" (employing "KBr pellet" procedure). "Avance-II (Bruker) 400 MHz NMR spectrophotometer" was employed for taking Proton nuclear magnetic resonance $\left({ }^{1} \mathrm{H}-\mathrm{NMR}\right)$ and Carbon nuclear magnetic resonance $\left({ }^{13} \mathrm{C}-\mathrm{NMR}\right)$ spectra consuming appropriate dutereated solvent and conferred in parts per million $(\delta, \mathrm{ppm})$ downfield from tetramethylsilane (internal reference).

\section{General procedure for preparation of designed molecules}

Dry benzoic acid ( $1 \mathrm{mmol}$ ) was added to a flat bottom flask fixed on a magnetic stirrer at constant temperature around $10^{\circ} \mathrm{C}$. Excess of sulfurochloridic acid $(8.0 \mathrm{ml})$ was added carefully and observed to avoid any escape. When all the acid was liquefied and the exothermic response terminated, the flat bottom flask was heated at $70-80^{\circ} \mathrm{C}$ using water bath for 2 hours, followed by cooling. The materials of the flask were poured into crushed ice (150 g) with stirring and crystals of 3-(chlorosulfonyl)benzoic

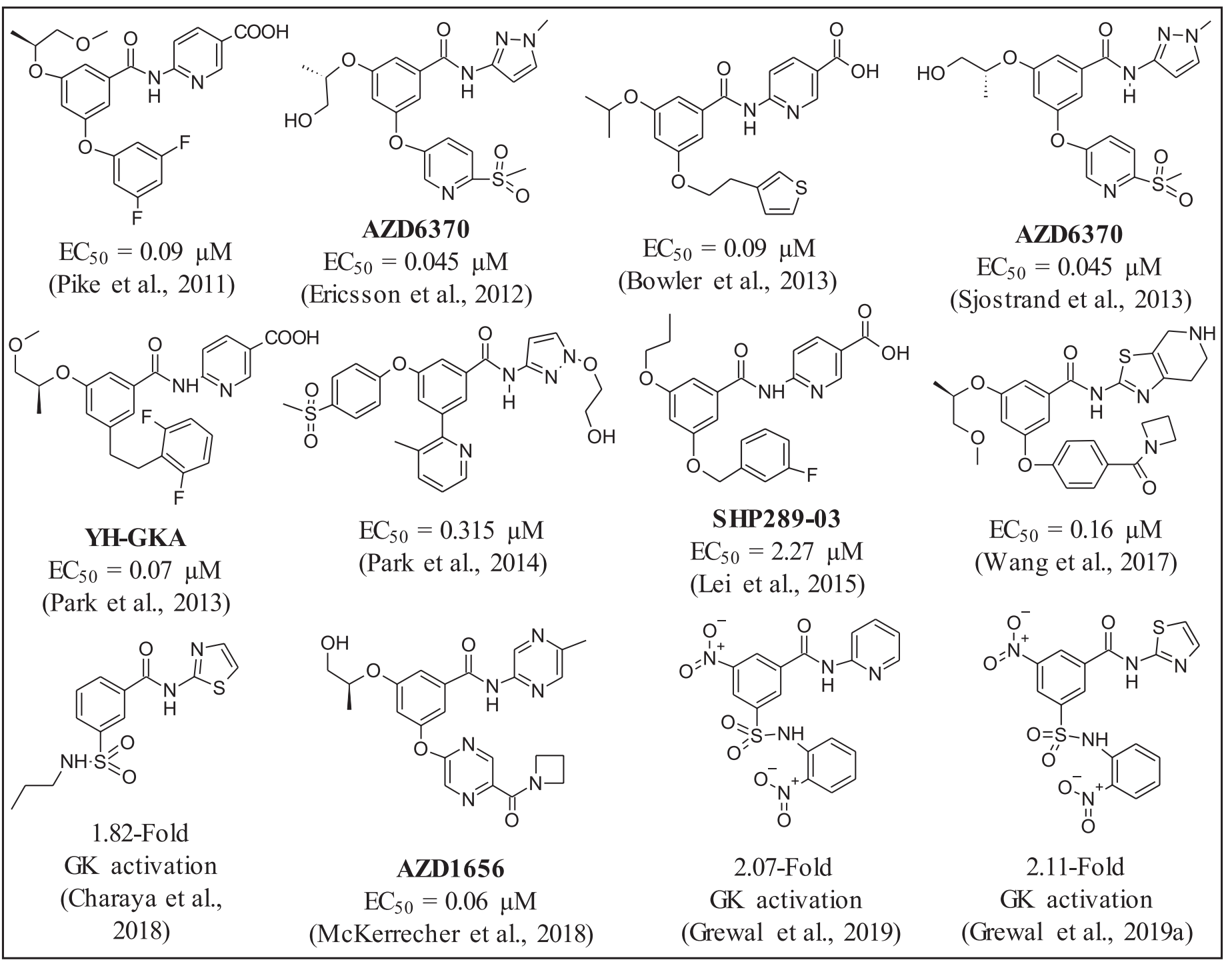

Figure 1. Some of the recently reported benzamide derivatives as potent GK activators. 
acid were filtered employing vacuum subsequent to cold water wash, followed by air drying. The precipitates prepared earlier ( $1 \mathrm{mmol}$ ) were then reacted with the corresponding aliphatic and aromatic amines $(1 \mathrm{mmol})$ under reflux using acetone till completion of the reaction (observed using TLC), following cooling and drying of the precipitates. The different sulfonamides prepared earlier $(1 \mathrm{mmol})$ were refluxed with sulfinyl chloride (1 mmol) for 3 hours and extra sulfinyl chloride was removed to obtain the analogous acid chlorides. Acid chlorides prepared earlier $(1 \mathrm{mmol})$ were refluxed with 2-aminobenzothiazole $(1.5$ $\mathrm{mmol})$. The end products obtained by evaporation of solvent were purified using recrystallization from ethanol (Grewal et al., 2017; Singh et al., 2017).

\section{N-(1,3-benzothiazol-2-yl)-3-(phenylsulfamoyl)benzamide (1)}

FTIR (KBr Pellets) $v \mathrm{~cm}^{-1}: 3,867.78$ (NH str.), 3,737.50 (NH str.), 3,432.08.46 (NH str.), 2,973.38 (CH str.), 1,642.58 $(\mathrm{C}=\mathrm{O}$ str. $), 1,558.12$ ( $\mathrm{NH}$ bend $), 1,463.36(\mathrm{C}=\mathrm{N}$ str. $), 1,417.54$ ( $\mathrm{C}=\mathrm{C}$ str.), 1,296.70 ( $\mathrm{SO}_{2}$ asym. str.), 1,076.13 ( $\mathrm{SO}_{2}$ sym. str.), 752.08 (CH bend), 667.04 (C-S str.); ${ }^{1} \mathrm{H}-\mathrm{NMR}(\delta \mathrm{ppm}, 400 \mathrm{MHz}$, Dimethyl sulfoxide (DMSO-d $)$ ): $8.92(\mathrm{~s}, 1 \mathrm{H}, \mathrm{NH}), 8.24-8.52$ (m, 4H, CH), 7.34-8.26 (m, 4H, CH), 6.88-7.32 (m, 5H), 2.58 (s, $1 \mathrm{H}, \mathrm{NH}) ;{ }^{13} \mathrm{C}-\mathrm{NMR}(\delta \mathrm{ppm}, \mathrm{DMSO}-\mathrm{d} 6): 172.09(\mathrm{C}=\mathrm{N}), 164.46$ $(\mathrm{C}=\mathrm{O}), 152.34(\mathrm{C}), 136.32(\mathrm{C}), 135.38(\mathrm{C}), 131.78(\mathrm{CH}), 130.02$ (C), $128.32(\mathrm{C}), 127.13(\mathrm{CH}), 125.23(\mathrm{CH}), 123.43(\mathrm{CH}), 122.02$ $(\mathrm{CH}), 119.17(\mathrm{CH}), 118.64(\mathrm{CH})$.

\section{N-(1,3-Benzothiazol-2-yl)-3-[(2-chloro-4-nitrophenyl) sulfamoyl]benzamide (2)}

FTIR (KBr Pellets) $v \mathrm{~cm}^{-1}: 3,836.20$ (NH str.), 3,446.91 (NH str.), 2,928.28 (CH str.), 1,641.34 (C=O str.), 1,632.23 ( $\mathrm{NH}$ bend), 1,551.35 ( $\mathrm{C}=\mathrm{N}$ str.), 1,464.11 ( $\mathrm{NO}_{2}$ sym. str.), 1,413.94 ( $\mathrm{NO}_{2}$ asym. str.), 1,299.66 ( $\mathrm{SO}_{2}$ asym. str.), 1,079.66 ( $\mathrm{SO}_{2}$ sym. str.), 684.36 (C-Cl str.), 667.10 (C-S str.); ${ }^{1} \mathrm{H}-\mathrm{NMR}(\delta \mathrm{ppm}, 400 \mathrm{MHz}$, DMSO-d $): 9.04$ (s, 1H, NH), 8.02-8.48 (m, 4H, CH), 7.54-8.11 (m, 4H, CH), 6.98-8.12 (m, 3H, CH), 2.46 (s, 1H, NH); ${ }^{13} \mathrm{C}-\mathrm{NMR}$ $(\delta$ ppm, DMSO-d6): $169.78(\mathrm{C}=\mathrm{N}), 162.32(\mathrm{C}=\mathrm{O}), 151.56(\mathrm{C})$, $139.22(\mathrm{C}), 137.28(\mathrm{C}), 133.67(\mathrm{C}), 131.09(\mathrm{CH}), 130.88(\mathrm{C})$, $129.07(\mathrm{CH}), 128.57(\mathrm{C}), 127.46(\mathrm{CH}), 126.27(\mathrm{C}), 125.18(\mathrm{CH})$, $124.22(\mathrm{CH}), 122.24(\mathrm{CH}), 118.88(\mathrm{CH}), 115.16(\mathrm{CH})$.

\section{N-(1,3-benzothiazol-2-yl)-3-(benzylsulfamoyl)benzamide (3)}

FTIR (KBr Pellets) $v \mathrm{~cm}^{-1}: 3,755.80$ (NH str.), 3,448.08 (NH str.), 2,996.40 (CH str.), 2,912.85 (CH str.), 1,659.53 (C=O str.), 1,429.38 (NH bend), 1,311.51 ( $\mathrm{SO}_{2}$ asym. str.), 1,025.25 ( $\mathrm{SO}_{2}$ sym. str.), 696.02 (CH bend), 527.06 (C-S str.); ${ }^{1} \mathrm{H}-\mathrm{NMR}(\delta$ ppm, $\left.400 \mathrm{MHz}, \mathrm{DMSO}_{6}\right): 8.98$ (s, 1H, NH), 8.16-8.42 (m, 4H, $\mathrm{CH}), 7.68-8.32(\mathrm{~m}, 4 \mathrm{H}, \mathrm{CH}), 7.16-7.58(\mathrm{~m}, 5 \mathrm{H}, \mathrm{CH}), 6.24(\mathrm{t}, 1 \mathrm{H}$, $\mathrm{NH}), 4.42\left(\mathrm{~d}, 1 \mathrm{H}, \mathrm{CH}_{2}\right) ;{ }^{13} \mathrm{C}-\mathrm{NMR}(\delta \mathrm{ppm}, \mathrm{DMSO}-\mathrm{d} 6): 176.02$ $(\mathrm{C}=\mathrm{N}), 165.32(\mathrm{C}=\mathrm{O}), 152.34(\mathrm{C}), 141.46(\mathrm{C}), 140.06(\mathrm{C}), 134.45$ (C), $130.34(\mathrm{C}), 130.12(\mathrm{CH}), 127.24(\mathrm{CH}), 124.37(\mathrm{CH}), 122.10$ $(\mathrm{CH}), 119.43(\mathrm{CH}), 117.13(\mathrm{CH}), 48.32(\mathrm{CH})$.

\section{N-(1,3-Benzothiazol-2-yl)-3-(butylsulfamoyl)benzamide (4)}

FTIR (KBr Pellets) $v \mathrm{~cm}^{-1}: 3,754.38$ (NH str.), 3,448.26 (NH str.), 2,930.77 (CH str.), 2,962.66 (CH str.), 1,643.35 (C=O str.), 1,554.13 ( $\mathrm{NH}$ bend), 1,464.82 ( $\mathrm{C}=\mathrm{C}$ str.), 1,415.35 $\left(\mathrm{SO}_{2}\right.$ asym. str.), 1,076.78 ( $\mathrm{SO}_{2}$ sym. str.), 666.78 (C-S str.); ${ }^{1} \mathrm{H}-\mathrm{NMR}$ $\left(\delta \mathrm{ppm}, 400 \mathrm{MHz}, \mathrm{DMSO}-\mathrm{d}_{6}\right): 9.08(\mathrm{~s}, 1 \mathrm{H}, \mathrm{NH}), 7.80-8.12(\mathrm{~m}$, $4 \mathrm{H}, \mathrm{CH}), 7.63-8.38(\mathrm{~m}, 4 \mathrm{H}, \mathrm{CH}), 5.54(\mathrm{t}, 1 \mathrm{H}, \mathrm{NH}), 4.08(\mathrm{~m}, 2 \mathrm{H}$, $\left.\mathrm{CH}_{2}\right), 2.62\left(\mathrm{~m}, 2 \mathrm{H}, \mathrm{CH}_{2}\right), 1.78\left(\mathrm{~m}, 2 \mathrm{H}, \mathrm{CH}_{2}\right), 1.08\left(\mathrm{~m}, 3 \mathrm{H}, \mathrm{CH}_{3}\right)$; ${ }^{13} \mathrm{C}-\mathrm{NMR}(\delta \mathrm{ppm}, \mathrm{DMSO}-\mathrm{d} 6)$ : $174.46(\mathrm{C}=\mathrm{N}), 164.98(\mathrm{C}=\mathrm{O})$, $152.49(\mathrm{C}), 139.58(\mathrm{C}), 135.13(\mathrm{C}), 131.23(\mathrm{CH}), 130.34(\mathrm{CH})$, $129.22(\mathrm{CH}), 125.47(\mathrm{CH}), 124.78(\mathrm{CH}), 121.12(\mathrm{CH}), 119.32$ $(\mathrm{CH}), 118.34(\mathrm{CH}), 115.66(\mathrm{CH}), 45.08(\mathrm{CH}), 34.25(\mathrm{CH}), 20.88$ $(\mathrm{CH}), 15.46(\mathrm{CH})$.

\section{N-(1,3-Benzothiazol-2-yl)-3-(methylsulfamoyl)benzamide (5)}

FTIR (KBr Pellets) $v \mathrm{~cm}^{-1}: 3,798.48$ (NH str.), 3,448.44 (NH str.), 3,017.57 (CH str.), 2,966.14 (CH str.), 1,654.21 (C=O str.), 1,598.09 ( $\mathrm{NH}$ bend), 1,544.68 (C=N str.), 1,388.45 $\left(\mathrm{SO}_{2}\right.$ asym. str.), 1,189.77 ( $\mathrm{SO}_{2}$ sym. str.), 789.65 ( $\mathrm{CH}$ bend), 665.88 (C-S str.); ${ }^{1} \mathrm{H}-\mathrm{NMR}\left(\delta \mathrm{ppm}, 400 \mathrm{MHz}, \mathrm{DMSO}-\mathrm{d}_{6}\right): 8.88(\mathrm{~s}, 1 \mathrm{H}$, $\mathrm{NH}), 7.94-8.43$ (m, 4H, CH), 7.45-8.16 (m, 4H, CH), 5.34 (t, $1 \mathrm{H}$, $\mathrm{NH}), 2.44\left(\mathrm{~s}, 3 \mathrm{H}, \mathrm{CH}_{3}\right) ;{ }^{13} \mathrm{C}-\mathrm{NMR}(\delta \mathrm{ppm}, \mathrm{DMSO}-\mathrm{d} 6): 175.36$ $(\mathrm{C}=\mathrm{N}), 165.23(\mathrm{C}=\mathrm{O}), 153.02(\mathrm{C}), 139.14(\mathrm{C}), 135.35(\mathrm{C}), 133.89$ $(\mathrm{CH}), 133.13(\mathrm{C}), 132.06(\mathrm{CH}), 128.98(\mathrm{CH}), 125.83(\mathrm{CH}), 124.24$ $(\mathrm{CH}), 121.56(\mathrm{CH}), 119.18(\mathrm{CH}), 118.11(\mathrm{CH}), 33.29(\mathrm{CH})$.

\section{N-(1,3-benzothiazol-2-yl)-3-[(2-methylphenyl)sulfamoyl] benzamide (6)}

FTIR (KBr Pellets) $v \mathrm{~cm}^{-1}: 3,791.96$ (NH str.), 3,456.56 (NH str.), 3,013.67 (CH str.), 2,912.67 (CH str.), 1,667.25 (C=O str.), 1,604.66 ( $\mathrm{NH}$ bend), 1,578.56 (C=N str.), 1,345.34 $\left(\mathrm{SO}_{2}\right.$ asym. str.), 1,103.78 ( $\mathrm{SO}_{2}$ sym. str.), 850.55 (CH bend), 664.89 (C-S str.); ${ }^{1} \mathrm{H}-\mathrm{NMR}\left(\delta \mathrm{ppm}, 400 \mathrm{MHz}, \mathrm{DMSO}-\mathrm{d}_{6}\right): 8.89(\mathrm{~s}, 1 \mathrm{H}$, $\mathrm{NH}), 8.08-8.43(\mathrm{~m}, 4 \mathrm{H}, \mathrm{CH}), 7.42-8.08(\mathrm{~m}, 4 \mathrm{H}, \mathrm{CH}), 6.44-7.25$ $(\mathrm{m}, 4 \mathrm{H}, \mathrm{CH}), 2.54(\mathrm{~s}, 1 \mathrm{H}, \mathrm{NH}), 2.43\left(\mathrm{~s}, 3 \mathrm{H}, \mathrm{CH}_{3}\right) ;{ }^{13} \mathrm{C}-\mathrm{NMR}(\delta$ ppm, DMSO-d6): $175.69(\mathrm{C}=\mathrm{N}), 166.96(\mathrm{C}=\mathrm{O}), 152.68(\mathrm{C})$, $139.46(\mathrm{C}), 138.12(\mathrm{C}), 135.42(\mathrm{C}), 134.08(\mathrm{C}), 134.87(\mathrm{CH})$, $133.67(\mathrm{C}), 132.12(\mathrm{CH}), 129.61(\mathrm{CH}), 126.59(\mathrm{CH}), 124.32$ $(\mathrm{CH}), 123.56(\mathrm{CH}), 121.27(\mathrm{CH}), 118.25(\mathrm{CH}), 18.37(\mathrm{CH})$.

\section{N-(1,3-benzothiazol-2-yl)-3-[(4-bromophenyl)sulfamoyl] benzamide (7)}

FTIR (KBr Pellets) $v \mathrm{~cm}^{-1}: 3,837.14$ (NH str.), 3,732.98 (NH str.), 3,441.64 (NH str.), 2,974.87 (CH str.), 1,641.67 (C=O str.), 1,553.91 ( $\mathrm{NH}$ bend), 1,464.33 (C=N str.), 1,415.88 $\left(\mathrm{SO}_{2}\right.$ asym. str.), 1,296.76 ( $\mathrm{SO}_{2}$ sym. str.), 809.70 ( $\mathrm{CH}$ bend), 753.82 (C-Br str.), 665.74 (C-S str.); ${ }^{1} \mathrm{H}-\mathrm{NMR}(\delta \mathrm{ppm}, 400 \mathrm{MHz}$, DMSO-d $): 8.75$ (s, 1H, NH), 8.14-8.38 (m, 4H, CH), 6.85-8.03 (m, 4H, CH), 7.06-7.38 (m, 4H, CH), 2.59 (s, 1H, NH); ${ }^{13} \mathrm{C}-\mathrm{NMR}$ ( $\delta$ ppm, DMSO-d6): $176.08(\mathrm{C}=\mathrm{N}), 166.34(\mathrm{C}=\mathrm{O}), 153.12(\mathrm{C})$, $139.10(\mathrm{C}), 137.05(\mathrm{C}), 134.28(\mathrm{C}), 132.72(\mathrm{CH}), 130.06(\mathrm{CH})$, $129.73(\mathrm{CH}), 127.32(\mathrm{CH}), 124.94(\mathrm{CH}), 121.74(\mathrm{CH}), 120.21$ $(\mathrm{CH}), 116.36(\mathrm{C})$.

\section{N-(1,3-benzothiazol-2-yl)-3-[(4-nitrophenyl)sulfamoyl] benzamide (e8)}

FTIR (KBr Pellets) $v \mathrm{~cm}^{-1}: 3,870.59$ (NH str.), 3,755.40 (NH str.), 3,452.66 (NH str.), 2,997.49 (CH str.), 1,708.27 (C=O str.), 1,429.03 ( $\mathrm{NO}_{2}$ sym. str.), 1,362.55 ( $\mathrm{NO}_{2}$ asym. str.), 1,311.98 
( $\mathrm{SO}_{2}$ asym. str.), 1,223.02 ( $\mathrm{SO}_{2}$ sym. str.), 696.02 ( $\mathrm{CH}$ bend), 526.51 (C-S str.); ${ }^{1} \mathrm{H}-\mathrm{NMR}\left(\delta \mathrm{ppm}, 400 \mathrm{MHz}, \mathrm{DMSO}-\mathrm{d}_{6}\right): 8.84(\mathrm{~s}$, $1 \mathrm{H}, \mathrm{NH}), 8.28-8.58(\mathrm{~m}, 4 \mathrm{H}, \mathrm{CH}), 7.89-8.17$ (m, 4H, CH), 6.68$7.85(\mathrm{~m}, 4 \mathrm{H}, \mathrm{CH}), 2.50(\mathrm{~s}, 1 \mathrm{H}, \mathrm{NH}) ;{ }^{13} \mathrm{C}-\mathrm{NMR}(\delta \mathrm{ppm}, \mathrm{DMSO}-\mathrm{d} 6)$ : $174.24(\mathrm{C}=\mathrm{N}), 165.89(\mathrm{C}=\mathrm{O}), 153.12(\mathrm{C}), 143.04(\mathrm{C}), 139.16(\mathrm{C})$, $137.32(\mathrm{C}), 134.04(\mathrm{C}), 133.89(\mathrm{C}), 129.82(\mathrm{CH}), 124.22(\mathrm{CH})$, $121.01(\mathrm{CH}), 120.84(\mathrm{CH}), 119.25(\mathrm{CH}), 116.39(\mathrm{CH})$.

\section{N-(1,3-benzothiazol-2-yl)-3-[(4-methylphenyl)sulfamoyl] benzamide (9)}

FTIR (KBr Pellets) $v \mathrm{~cm}^{-1}: 3,868.16$ (NH str.), 3,754.28 (NH str.), 3,448.36 (NH str.), 2,930.77 (CH str.), 1,643.31 ( $\mathrm{C}=\mathrm{O}$ str.), 1,553.03 ( $\mathrm{NH}$ bend), 1,464.83 ( $\mathrm{C}=\mathrm{N}$ str.), 1,415.35 ( $\mathrm{CH}$ bend), 1,300.62 ( $\mathrm{SO}_{2}$ asym. str.), 1,076.79 ( $\mathrm{SO}_{2}$ sym. str.), 717.52 (CH bend), 666.77 (C-S str.); ${ }^{1} \mathrm{H}-\mathrm{NMR}(\delta \mathrm{ppm}, 400 \mathrm{MHz}$, DMSO-d $)_{6}: 8.76(\mathrm{~s}, 1 \mathrm{H}, \mathrm{NH}), 7.98-8.28(\mathrm{~m}, 4 \mathrm{H}, \mathrm{CH}), 7.32-7.75$ (m, 4H, CH), 6.32-7.23 (m, 4H, CH), $2.51(\mathrm{~s}, 1 \mathrm{H}, \mathrm{NH}), 2.36(\mathrm{~s}$, $\left.3 \mathrm{H}, \mathrm{CH}_{3}\right) ;{ }^{13} \mathrm{C}-\mathrm{NMR}(\delta \mathrm{ppm}, \mathrm{DMSO}-\mathrm{d} 6): 176.03(\mathrm{C}=\mathrm{N}), 165.94$ $(\mathrm{C}=\mathrm{O}), 153.12$ (C), 139.88 (C), 136.65 (C), 135.14 (C), 133.74 (C), $132.64(\mathrm{C}), 130.95(\mathrm{CH}), 129.18(\mathrm{CH}), 125.34(\mathrm{CH}), 124.04$ $(\mathrm{CH}), 120.84(\mathrm{CH}), 119.23(\mathrm{CH}), 118.06(\mathrm{CH}), 25.98(\mathrm{CH})$.

\section{N-(1,3-Benzothiazol-2-yl)-3-(propylsulfamoyl)benzamide (10)}

FTIR (KBr Pellets) $v \mathrm{~cm}^{-1}: 3,450.06$ (NH str.), 2,996.68 (NH str.), 2,912.98 (CH str.), 1,689.51 (C=O str.), 1,428.92 (NH bend), 1,311.73 ( $\mathrm{C}=\mathrm{N}$ str. $), 1,023.65\left(\mathrm{SO}_{2}\right.$ asym. str. $), 950.47\left(\mathrm{SO}_{2}\right.$ sym. str.), 696.27 (CH bend), 524.89 (C-S str.); ${ }^{1} \mathrm{H}-\mathrm{NMR}(\delta \mathrm{ppm}$, $\left.400 \mathrm{MHz}, \mathrm{DMSO}-\mathrm{d}_{6}\right): 9.11$ (s, 1H, NH), 8.20-8.43 (s, 3H, CH), 7.58-8.12 (m, 4H, CH), 6.34 (t, 1H, NH), 3.94 (m, 2H, $\left.\mathrm{CH}_{2}\right), 2.65$ $\left(\mathrm{m}, 2 \mathrm{H}, \mathrm{CH}_{2}\right), 1.24\left(\mathrm{t}, 3 \mathrm{H}, \mathrm{CH}_{3}\right) ;{ }^{13} \mathrm{C}-\mathrm{NMR}(\delta \mathrm{ppm}, \mathrm{DMSO}-\mathrm{d} 6)$ : $175.24(\mathrm{C}=\mathrm{N}), 165.14(\mathrm{C}=\mathrm{O}), 154.23(\mathrm{C}), 138.42(\mathrm{C}), 134.64$ (C), $130.54(\mathrm{C}), 129.18(\mathrm{CH}), 125.26(\mathrm{CH}), 120.47(\mathrm{CH}), 119.08$ $(\mathrm{CH}), 117.56(\mathrm{CH}), 44.28(\mathrm{CH}), 31.08(\mathrm{CH}), 16.22(\mathrm{CH})$.

\section{In vitro GK assay}

GK activation potential of all the derivatives was assessed by employing a combined response with glucose-6phosphate dehydrogenase (G6PDH) using spectrometry (Efanov et al., 2005; Futamura et al., 2006; Grewal et al., 2019c). All the samples were made using DMSO and the in-vitro GK test was conducted in a final volume of $2,000 \mu \mathrm{l}$ comprising $0.25 \mathrm{mM}$ 4-(2-Hydroxyethyl)-1-piperazineethanesulfonic acid ( $\mathrm{pH} 7.4$ ), $10 \mathrm{mM}$ dextrose, $25 \mathrm{mM} \mathrm{KCl}, 1 \mathrm{mM} \mathrm{MgCl}_{2}, 1 \mathrm{mM}$ 1,4-dithioD-threitol, $1 \mathrm{mM}$ nicotinamide adenine dinucleotide, $1 \mathrm{mM}$ ATP, G6PDH $(2.5 \mathrm{U} / \mathrm{ml}), 0.5 \mu \mathrm{g} \mathrm{GK}$, and derivatives to be tested (10 $\mu \mathrm{M})$. Readings were taken at $340 \mathrm{~nm}$ following a nurture time of 3 minutes and GK activation was computed in comparison to DMSO (activation of GK by DMSO alone was treated as $100 \%$ ). All the results were represented as mean $(n=3) \pm$ standard deviation. The in vitro GK assay data for test groups were statistically analyzed by one-way analysis of variance for comparison and significance from control group (value of $p<0.05$ ) using GraphPad Prism (GraphPad Software Inc.).

\section{In silico prediction of pharmacokinetic parameters}

All the designed molecules were analyzed for the prediction of pharmacokinetic parameters related to absorption, distribution, metabolism, and excretion (ADME) by employing FAF-Drugs4 server; and accessed using Lipinski's rule of 5 for drug-likeness (Lagorce et al., 2017; Miteva et al., 2006).

\section{Molecular docking investigations}

Molecular docking investigations were carried out for all the analogs in the allosteric binding location of the GK employing AutoDock Vina and AutoDock Tools (ADTs) (Morris et al., 2009; Trott and Olson, 2010). The 2D chemical structures of all the ligands were prepared by MarvinSketch 18.5.0 (ChemAxon), followed by conversion to 3D by Frog2 (Miteva et al., 2010). The ligands were converted into "pdbqt" files using ADTs. After assessing a number of co-crystallized structures for GK available in the protein data bank; the best ligand bound complex was selected based on higher resolution and key binding interactions between the GK and small molecule activators (Protein data bank (PDB) ID: 3IMX). The PDB file of the GK protein were edited using PyMOL (Schrödinger, Limited liability company.) by removing the cocrystallized activator, entirely water molecules along with other non-interacting species. The "pdbqt" files of target proteins were produced from the PDB files using ADTs. The "grid" tool of ADTs was used to calculate the grid parameters and all the information concerning target protein, ligand, grid size, and geometry were saved in "txt" file. The reference ligand was docked with GK and compared with that of reference GK activator for determining accuracy of docking protocol. The 3D optimized ligands were docked with the refined GK protein and scored by scoring function. The binding free energy $(\Delta \mathrm{G}, \mathrm{kcal} / \mathrm{mol})$ for each compound was reported in a log file and the binding interactions of the ligands in binding site of the target proteins were analyzed using Name of graphics tool (Grewal et al., 2019b; Rathee et al., 2019).

\section{In silico prediction of toxicity}

All the compounds were evaluated in silico for the prediction of possible toxicity of these compounds using Name of tool used for prediction of pharmacokinetic properties online computer program (Pires et al., 2015, 2018; Salgueiro et al., 2016).<smiles>[R]NC(=O)c1cccc(S(=O)(=O)N[R])c1</smiles>

Scheme 1. General synthetic route followed for N-benzothiazol-2-yl benzamide analogs. Reagents and conditions: (a) $\mathrm{HClSO}_{3}$; (b) $\mathrm{NH}_{2}-\mathrm{R}^{1}$, reflux; (c) $\mathrm{SO}_{2} \mathrm{Cl}_{\text {, reflux; }}$ (d) $\mathrm{NH}_{2}-\mathrm{R}^{2}$, reflux. 
Table 1. Physicochemical properties of the synthesized N-benzothiazol-2-yl benzamide analogs.

\begin{tabular}{|c|c|c|c|c|c|c|}
\hline Compound & $\mathbf{R}$ & $\mathbf{R}$ & Mol. formula & M. Pt. $\left({ }^{\circ} \mathrm{C}\right)$ & $\mathbf{R}_{\mathrm{f}}^{\mathrm{a}}$ & $\%$ Yield \\
\hline 1 & $-\mathrm{C}_{6} \mathrm{H}_{5}$ & & $\mathrm{C}_{20} \mathrm{H}_{15} \mathrm{~N}_{3} \mathrm{O}_{3} \mathrm{~S}_{2}$ & $152-154$ & 0.62 & 66 \\
\hline 2 & & & $\mathrm{C}_{20} \mathrm{H}_{13} \mathrm{ClN}_{4} \mathrm{O}_{5} \mathrm{~S}_{2}$ & $168-171$ & 0.57 & 72 \\
\hline 3 & $-\mathrm{CH}_{2} \mathrm{C}_{6} \mathrm{H}_{4}$ & & $\mathrm{C}_{21} \mathrm{H}_{17} \mathrm{~N}_{3} \mathrm{O}_{3} \mathrm{~S}_{2}$ & $160-165$ & 0.56 & 49 \\
\hline 4 & $-\mathrm{C}_{4} \mathrm{H}_{9}$ & & $\mathrm{C}_{18} \mathrm{H}_{19} \mathrm{~N}_{3} \mathrm{O}_{3} \mathrm{~S}_{2}$ & $143-146$ & 0.69 & 59 \\
\hline 5 & $-\mathrm{CH}_{3}$ & & $\mathrm{C}_{15} \mathrm{H}_{13} \mathrm{~N}_{3} \mathrm{O}_{3} \mathrm{~S}_{2}$ & $135-138$ & 0.76 & 57 \\
\hline 6 & & & $\mathrm{C}_{21} \mathrm{H}_{17} \mathrm{~N}_{3} \mathrm{O}_{3} \mathrm{~S}_{2}$ & $165-168$ & 0.48 & 77 \\
\hline 7 & & & $\mathrm{C}_{20} \mathrm{H}_{14} \mathrm{BrN}_{3} \mathrm{O}_{3} \mathrm{~S}_{2}$ & $172-175$ & 0.77 & 73 \\
\hline 8 & & & $\mathrm{C}_{21} \mathrm{H}_{17} \mathrm{~N}_{3} \mathrm{O}_{3} \mathrm{~S}_{2}$ & $163-166$ & 0.68 & 63 \\
\hline 9 & & & $\mathrm{C}_{20} \mathrm{H}_{14} \mathrm{~N}_{4} \mathrm{O}_{5} \mathrm{~S}_{2}$ & $159-163$ & 0.64 & 67 \\
\hline 10 & $-\mathrm{C}_{3} \mathrm{H}_{7}$ & & $\mathrm{C}_{17} \mathrm{H}_{17} \mathrm{~N}_{3} \mathrm{O}_{3} \mathrm{~S}_{2}$ & $165-170$ & 0.73 & 45 \\
\hline
\end{tabular}

TLC mobile phase: Toluene: Ethyl acetate (7:3).

\section{RESULTS AND DISCUSSION}

\section{Chemistry}

3-(Chlorosulfonyl)benzoic acid attained via chlorosulfonation of benzoic acid was reacted with various amines to get the sulfonamides. These sulfonamides were then reacted with thionyl chloride, followed by reaction with 2-aminobenzothiazole to synthesize the desired compounds (Scheme 1) in good yield (Table 1).

The ${ }^{1} \mathrm{H}-\mathrm{NMR}$ spectra of the prepared analogues exhibited the singlet signal corresponding to 1 proton of CONH scaffold in the range $\delta$ 9-10 ppm, therefore, supporting the development of benzamide connection in these derivatives. The occurrence of singlet signal for $1 \mathrm{NH}$ proton of sulfonamide moiety at about $\delta$ $2.5 \mathrm{ppm}$ depicted the synthesis of sulfonamide analogues by the reaction of sulfonyl chloride derivatives with the corresponding amines. The existence of one singlet signal (equivalent to $\mathrm{C}_{2}$ ), two doublet signals (corresponding to $\mathrm{C}_{4}$ and $\mathrm{C}_{6}$ ), and a triplet signal (corresponding to $\mathrm{C}_{5}$ ) around $\delta 7.5-8$ ppm of the benzamide scaffold established the fact that the benzamide and sulfonamide functional moieties were located meta to each other. Two doublets and two triplet signals corresponding to four protons (aromatic $\mathrm{CH}$ ) were detected at about $\delta 7-8 \mathrm{ppm}$ in the ${ }^{1} \mathrm{H}-\mathrm{NMR}$ spectra of these molecules approving that the designed derivatives were synthesized 
by reacting benzoyl chloride with 2 -aminobenzothiazole. In the ${ }^{13} \mathrm{C}$-NMR spectra of the prepared molecules signals around $\delta 175$ ppm indicated the existence of $\mathrm{C}=\mathrm{N}$ bond in these derivatives and signals around $\delta 165$ ppm indicated presence of amide $\mathrm{C}=\mathrm{O}$ bond therefore supporting the formation of benzamide linkage in these derivatives. The FTIR spectra of these molecules exhibited $\mathrm{NH}$-stretching vibrations (for amide) $>3,500 \mathrm{~cm}^{-1} ; \mathrm{CH}$-stretching (aromatic) vibrations $>3,000 \mathrm{~cm}^{-1} ; \mathrm{SO}_{2}$ stretching vibrations (asymmetric and symmetric) in the range of 1,399-1,301 $\mathrm{cm}^{-1}$ and 1,199-1,101 $\mathrm{cm}^{-1}$, respectively; and $\mathrm{SO}_{2} \mathrm{NH}$ stretching peaks at around 3,399-3,101 $\mathrm{cm}^{-1}$, thus confirming the presence of a benzamide functional group (CONH) and a sulfonamide moiety these newly prepared analogs. In the FTIR spectra of these compounds stretching vibrations for $\mathrm{C}=\mathrm{O}$ at around $1,699-1,601$ $\mathrm{cm}^{-1}$ supported the occurrence of benzamide carbonyl moiety in the construction of these analogues. The occurrence of the NHbending vibrations near to $1,600 \mathrm{~cm}^{-1}$ depicted the presence of aromatic NH-moiety in the construction of these molecules.

\section{In vitro GK assay}

The outcomes of the in vitro GK test (activation of GK enzyme by the synthesized derivatives compared to control) are shown in Figure 2. Among the synthesized compounds evaluated, $\mathbf{1 , 2 , 6}$, and 7 revealed maximum GK activity in the GK test (GK

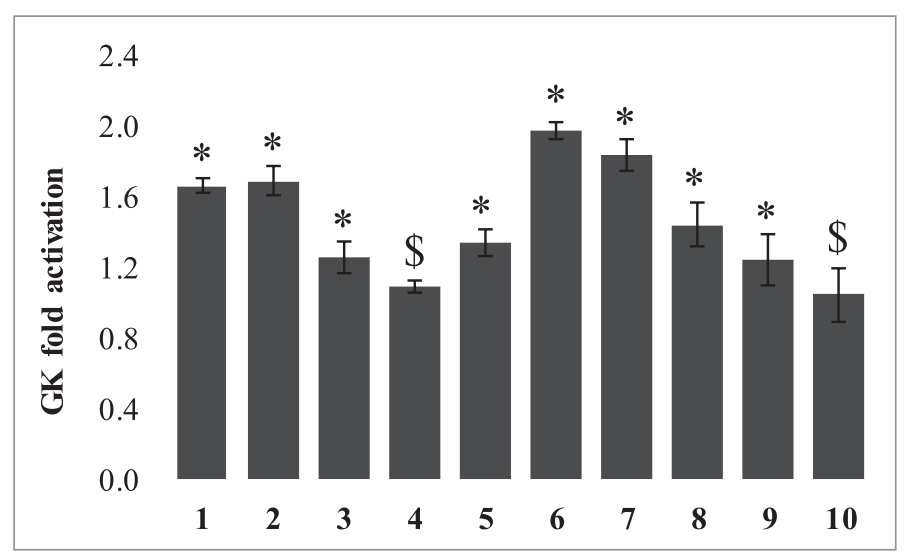

Figure 2. GK activity (GK fold activation) of the synthesized derivatives (at 10$\mu \mathrm{M}$ concentration). ${ }^{*}$ Data were significantly dissimilar compared to control ( $p$ $<0.05)$. ${ }^{\$}$ Data were not significantly dissimilar compared to control $(p>0.05)$. activation fold in the range of 1.6-2.0 compared to control). Compounds $\mathbf{5}$ and $\mathbf{8}$ disclosed moderate GK activation (fold activation in the range of 1.3-1.5) of GK enzyme. Compounds 3 and 9 demonstrated poor GK activity (fold activation about 1.20) in comparison to that of control. Compounds $\mathbf{4}$ and $\mathbf{1 0}$ were unsuccessful in the in vitro GK assay.

Among the synthesized analogs, compounds bearing N-(2-methylphenyl) sulfonamide moiety (compound 6) exhibited highest GK activity (GK activation fold of 1.97). Derivative bearing N-4-bromophenyl substituted sulfonamide moiety (compound 7) displayed potent 1.84-fold activation in comparison to that of the control. Analogs having N-phenyl and N-2-chloro-4-nitrophenyl sulfonamide moiety ( $\mathbf{1}$ and $\mathbf{2}$, respectively) demonstrated 1.66 and 1.69-fold GK activation, correspondingly. Synthesized compounds having N-4-nitrophenyl and N-methyl sulfonamide moiety (5 and 8, respectively) exhibited moderate GK activity (1.34 and 1.44-fold GK activation, respectively). Analogs bearing N-benzyl and N-4methylphenyl sulfonamide moiety ( 3 and 9 , respectively) exhibited poor GK activity (1.26 and 1.24-fold activation, correspondingly). Derivatives having N-butyl and N-propyl sulfonamide moiety (compounds 4 and 10, respectively) were ineffective in the GK assay. Outcomes of the GK test demonstrated that replacement of substituted phenyl moiety substituted to $\mathrm{SO}_{2} \mathrm{NH}$ resulted in improved GK activity compared to those having alkyl group as can be seen from GK activity of compounds $\mathbf{1 , 2 , 6}$, and 7. Substitution of aromatic moiety attached to $\mathrm{SO}_{2} \mathrm{NH}$ with alkyl chains led to reduced GK activation potential compared to compounds having aromatic moiety as can be seen from GK activity of compounds $\mathbf{4 , 5}$, and $\mathbf{1 0}$.

\section{Prediction of ADME properties}

ADME parameters, including molecular weight (MW), partition coefficient $(\log \mathrm{P})$, distribution coefficient $(\log \mathrm{D})$, water solubility $\left(\log \mathrm{S}_{\mathrm{w}}\right)$, "topological polar surface area" (tPSA), "H-bond acceptors" (HBA), "H-bond donors" (HBD), solubility $(\mathrm{mg} / \mathrm{l})$ and "number of rotatable bonds" (NRB), were predicted for all the designed compounds. All of the designed compounds showed good pharmacokinetic parameters for oral bioavailability (Table 2) and drug-like properties as described using "Lipinski's rule of 5" (Pfizer's rule of five or simply rule of five).

\section{In silico docking investigations}

The reference ligand of PDB ID of the protein structure used in docking studies was docked with GK; and the docked reference

Table 2. Predicted ADME properties of the designed compounds.

\begin{tabular}{|c|c|c|c|c|c|c|c|c|c|}
\hline Compound & MW & $\log P$ & $\log D$ & $\log S_{w}$ & tPSA & HBA & HBD & Solubility & NRB \\
\hline 1 & 409.5 & 4.07 & 4.22 & -5.02 & 124.8 & 6 & 2 & $2,696.1$ & 4 \\
\hline 2 & 488.9 & 4.53 & 4.40 & -5.72 & 170.6 & 9 & 2 & $1,596.9$ & 5 \\
\hline 3 & 423.5 & 4.01 & 4.43 & -4.98 & 124.8 & 6 & 2 & $2,900.2$ & 5 \\
\hline 4 & 389.5 & 3.76 & 4.03 & -4.46 & 124.8 & 6 & 2 & $4,513.1$ & 6 \\
\hline 5 & 347.4 & 2.51 & 2.71 & -3.67 & 124.8 & 6 & 2 & $8,894.9$ & 3 \\
\hline 6 & 423.5 & 4.44 & 4.76 & -5.32 & 124.8 & 6 & 2 & $2,070.7$ & 4 \\
\hline 7 & 488.4 & 4.76 & 4.98 & -5.95 & 124.8 & 6 & 2 & $1,276.5$ & 4 \\
\hline 8 & 454.5 & 3.09 & 4.06 & -5.11 & 170.6 & 9 & 2 & $2,733.3$ & 5 \\
\hline 9 & 423.5 & 4.44 & 4.76 & -5.32 & 124.8 & 6 & 2 & $2,070.7$ & 4 \\
\hline 10 & 375.5 & 3.41 & 3.59 & -4.23 & 124.8 & 6 & 2 & $5,448.4$ & 5 \\
\hline
\end{tabular}


Table 3. Binding interactions and docking score $(\Delta \mathrm{G})$ of the docked designed derivatives.

\begin{tabular}{|c|c|c|c|c|}
\hline \multirow{2}{*}{ Ligand } & \multicolumn{2}{|c|}{ H-bond interactions } & \multirow{2}{*}{ Residues involved in hydrophobic interactions } & \multirow{2}{*}{$\Delta \mathbf{G}$} \\
\hline & Residues & Distance $(\AA)$ & & \\
\hline 1 & Arg63, Ser69 & $4.1,3.1,4.8$ & Pro66, Pro99, Ile159, Ile211, Tyr214, Ala454, Val455 & -8.4 \\
\hline 2 & Arg63 & $4.0,3.0$ & Pro66, Pro99, Ile159, Met 210, Ile211, Tyr214, Ala454, Va1455 & -9.3 \\
\hline 3 & $\operatorname{Arg} 63$ & $4.4,3.6$ & Pro66, Ile159, Ile211, Tyr214, Ala454 & -9.6 \\
\hline 4 & Arg63, Ser69 & $4.1,3.4,5.4$ & Pro66, Ile159, Ile211, Tyr214, Ala454, Val455 & -8.7 \\
\hline 5 & Arg63, Ser69 & $3.9,3.0,5.4$ & Pro66, Ile159, Met 210, Ile211, Tyr214, Ala454, Val455 & -8.6 \\
\hline 6 & $\operatorname{Arg} 63$ & $3.0,3.0$ & Pro66, Pro99, Ile159, , Ile211, Tyr214, Ala454, Val455 & -9.9 \\
\hline 7 & $\operatorname{Arg} 63$ & $3.9,3.3$ & Pro66, Pro99, Ile159, Ile211, Tyr214, Ala454 & -9.4 \\
\hline 8 & Arg63, Ser69 & $3.9,3.0,5.7$ & Pro66, Pro99, Ile159, Met 210, Ile211, Tyr214, Ala454, Val455 & -9.9 \\
\hline 9 & Arg63, Ser69 & $4.0,3.1,4.5$ & Pro66, Pro99, Ile159, Met 210, Ile211, Tyr214, Ala454 & -9.4 \\
\hline 10 & Ser69 & 3.9 & Pro66, Pro99, Ile159, Ile211, Tyr214, Ala454 & -7.5 \\
\hline
\end{tabular}
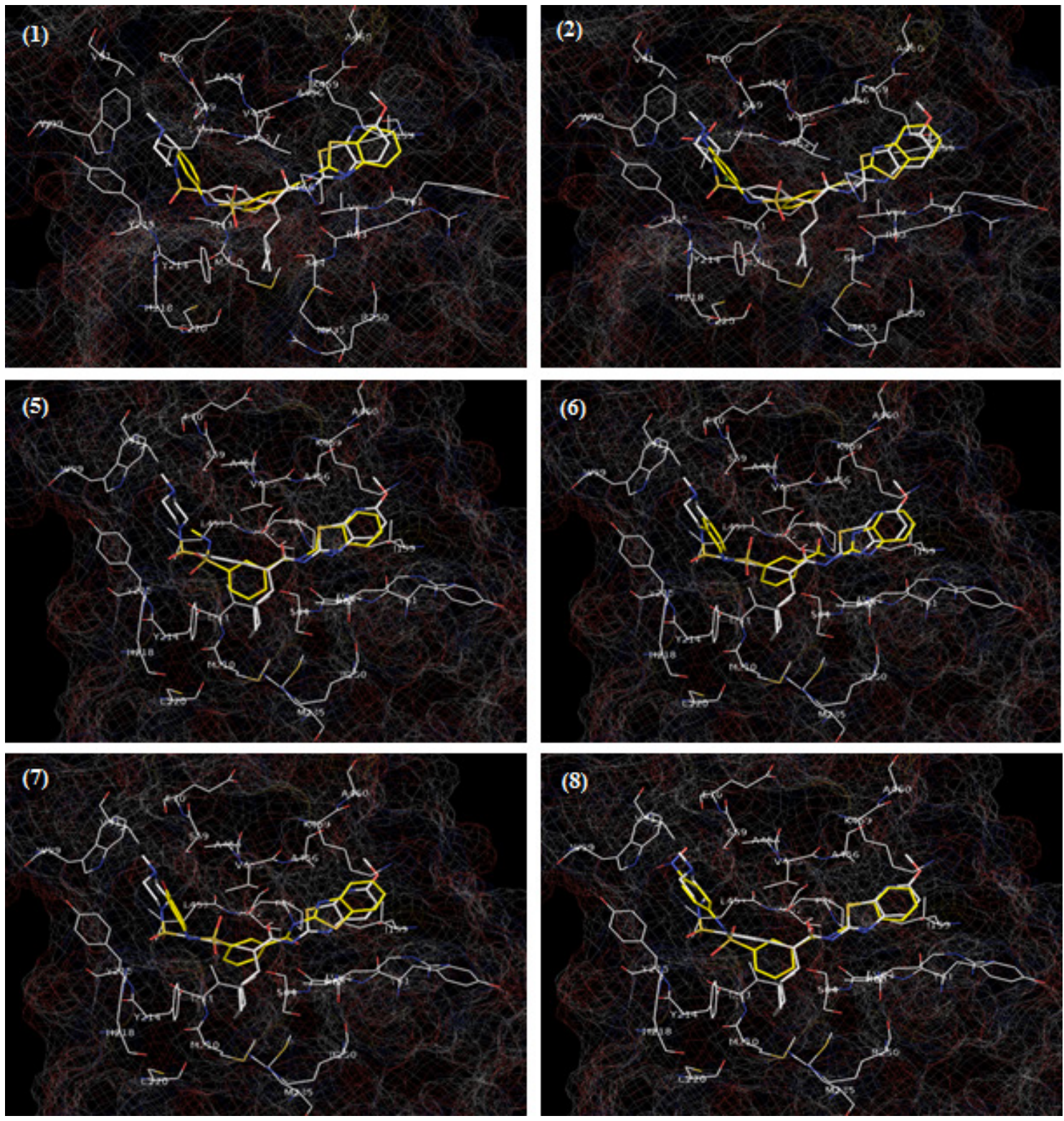

Figure 3. Superposition of the docked poses of compounds $\mathbf{1 , 2}, \mathbf{5 , 6}, \mathbf{7}$, and $\mathbf{8}$ (yellow stick) with that of PDB ligand of 3IMX (grey stick) in the allosteric binding site of GK protein. 

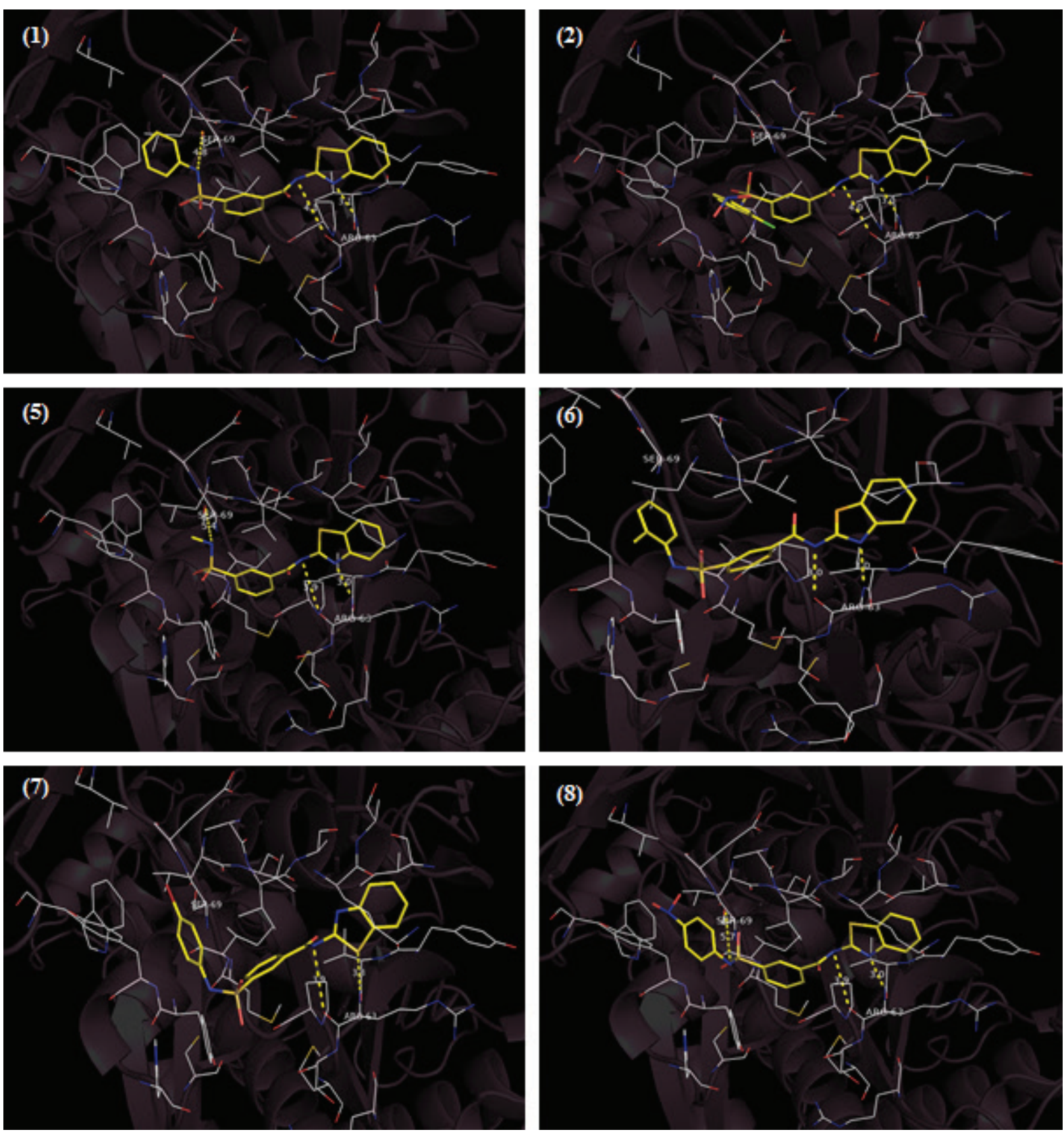

Figure 4. Best docked poses showing H-bond interactions of the compounds 1, 2, 5, 6, 7, and 8 with allosteric binding site residues of GK protein.

GK activator produced an analogous bonding outline and overlay on the binding mode of the co-crystallized activator with $\Delta \mathrm{G}$ of -9.0 $\mathrm{kcal} / \mathrm{mol}$ validating accuracy of docking methodology. Most of the docked ligands exhibited considerable binding with allosteric site residues of $\mathrm{GK}$ as established by analyzing their bonding interactions and $\Delta \mathrm{G}$ of the best docked poses. Based on their bottommost " $\Delta \mathrm{G}$ " values and docking connections with the allosteric site residues; compounds $1,2,5,6,7$, and 8 were additionally examined in minutiae using PyMOL for exploring binding interactions of these molecules with allosteric site residues of GK (Table 3).

Super-positioning of the docked poses of $\mathbf{1 , 2}, \mathbf{5}, \mathbf{6 , 7}$, and $\mathbf{8}$ on that of reference ligand in the allosteric site of GK protein demonstrated that the these molecules had the analogous binding and orientation arrangement in the allosteric site of GK as that of the co-crystallized activator (PDB entry: 3IMX) [“"(2R)-3-cyclopentyl$\mathrm{N}$-(5-methoxy[1,3]thiazolo[5,4-b]pyridin-2-yl]-2-\{4-[(4methylpiperazin-1-yl)sulfonyl]phenyl $\}$ propanamide") supporting the outcomes of in vitro GK test for these compounds (Fig. 3).

The docked pose of compounds $\mathbf{1}, \mathbf{2}, \mathbf{5}, \mathbf{6}, \mathbf{7}$, and 8 showed H-bond interactions between " $\mathrm{N}$ " of benzothiazol-2-yl group and amide $\mathrm{NH}$ of Arg63 residues; and "benzamide NH" group and "backbone $\mathrm{C}=\mathrm{O}$ " of $\mathrm{Arg} 63$ residue in the allosteric location of GK with bond length in the range $3.0 \AA-4.1 \AA$; and $3.0 \AA-3.3 \AA$, respectively. Overall, the benzothiazol-2-yl moiety bonded to the benzamide "NH" of these compounds projected in the hydrophobic cavity displaying connections with the Val455 and 
Table 4. Toxicity prediction for the optimized compounds obtained using pkCMS.

\begin{tabular}{|c|c|c|c|c|c|c|c|}
\hline Compound & Mutagenicity $^{\mathrm{a}}$ & Cardiotoxicity $^{b}$ & $\begin{array}{c}\text { Acute } \\
\text { toxicity }\end{array}$ & $\begin{array}{l}\text { Chronic } \\
\text { toxicity }^{\mathrm{d}}\end{array}$ & Hepatotoxicity & $\begin{array}{c}\text { Skin } \\
\text { irritation }\end{array}$ & $\begin{array}{c}\text { Max. tolerated } \\
\text { dose }^{\mathrm{e}}\end{array}$ \\
\hline 1 & No & No & 2.701 & 2.382 & No & No & 0.845 \\
\hline 2 & Yes & No & 2.554 & 1.957 & No & No & 0.138 \\
\hline 3 & No & No & 2.558 & 2.390 & No & No & 0.820 \\
\hline 4 & No & No & 2.071 & 1.787 & No & No & 0.560 \\
\hline 5 & No & No & 2.003 & 1.796 & No & No & 0.543 \\
\hline 6 & No & No & 2.447 & 2.865 & No & No & 0.556 \\
\hline 7 & No & No & 2.447 & 1.707 & No & No & 0.574 \\
\hline 8 & Yes & No & 2.374 & 3.056 & No & No & 0.673 \\
\hline 9 & No & No & 2.477 & 1.757 & No & No & 0.556 \\
\hline 10 & No & No & 2.053 & 1.777 & No & No & 0.575 \\
\hline \multicolumn{8}{|c|}{ "Mutagenicity was accessed using "AMES" test. } \\
\hline $\begin{array}{l}{ }^{\mathrm{b}} \text { Cardiotoxicity } \\
\text { cAcute toxicity: } \\
{ }^{\mathrm{d}} \text { Chronic toxicit }\end{array}$ & $\begin{array}{l}\text { as accessed using } \\
\text { Oral rat acute toxi } \\
\text { "Oral rat chronic }\end{array}$ & $\begin{array}{l}\text { RG-I and hERG-II } \\
\text { y }\left(\mathrm{LD}_{50} \text { in } \mathrm{mol} / \mathrm{kg}\right) \\
\text { xicity }(\mathrm{log} \mathrm{mg} / \mathrm{kg}\end{array}$ & $\begin{array}{l}\text { ibition. } \\
\text { lay)". }\end{array}$ & & & & \\
\hline 'Max. Tolerated & ose (human): "log & g/kg/day". & & & & & \\
\hline
\end{tabular}

Lys459 amino acid residues, along with Pro66 and Ile159 amino acid residues, aromatic moiety parceled in the cavity composed of Met210, Tyr214, and Val455 residues (Fig. 4).

\section{In silico prediction of toxicity}

The possible toxicity (mutagenic, cardiotoxicity, acute toxicity, hepatotoxicity, skin irritation, and chronic toxicity) for the optimized compounds was accessed using the pkCSM online platform. Conferring to the results represented in Table 4, all the compounds showed little toxicity probability. For all the compounds accessed in silico for prediction of toxicity using the online program, mutagenicity was predicted for compounds $\mathbf{2}$ and $\mathbf{8}$. In this perspective, the initial evaluation performed in silico can supplement forthcoming studies related to the safety of these compounds.

\section{CONCLUSION}

In summary, a series of novel N-benzothiazol-2-yl benzamide derivatives were designed and synthesized based on structure-based drug design approach. Among these newly identified derivatives, analogs 6 and 7 unveiled maximum GK activation potential ( $>1.6$-fold GK activation). Outcomes of the in-vitro GK test were found to be analogous to the in-silico docking investigations with the GK enzyme. These freshly developed compounds can assist in finding the lead analogues for ultimate discovery of strong and harmless activators of GK for T2D handling and management.

\section{ACKNOWLEDGMENTS}

The authors are thankful to Chitkara College of Pharmacy, Chitkara University, Rajpura, (Punjab) for their support and encouragement for this research work.

\section{AUTHOR CONTRIBUTIONS}

All authors made substantial contributions to conception and design, acquisition of data, or analysis and interpretation of data; took part in drafting the article or revising it critically for important intellectual content; agreed to submit to the current journal; gave final approval of the version to be published; and agree to be accountable for all aspects of the work.

\section{FUNDING}

There is no funding to report.

\section{CONFLICTS OF INTEREST}

The authors report no financial or any other conflicts of interest in this work

\section{ETHICAL APPROVALS}

This study does not involve the use of animals or human subjects.

\section{PUBLISHER'S NOTE}

This journal remains neutral with regard to jurisdictional claims in published institutional affiliation.

\section{REFERENCES}

Bastaki S. Diabetes mellitus and its treatment. Int J Diabetes Metab, 2005; 13:111-34.

Bowler JM, Hervert KL, Kearley ML, Miller BG. Smallmolecule allosteric activation of human glucokinase in the absence of glucose. ACS Med Chem Lett, 2013; 4(7):580-4.

Charaya N, Pandita D, Grewal AS, Lather V. Design, synthesis and biological evaluation of novel thiazol-2-yl benzamide derivatives as glucokinase activators. Comput Biol Chem, 2018; 73:221-9.

Coghlan M, Leighton B. Glucokinase activators in diabetes management. Expert Opin Investig Drugs, 2008; 17(2):145-67.

Efanov AM, Barrett DG, Brenner MB, Briggs SL, Delaunois A, Durbin JD, Giese U, Guo H, Radloff M, Gil GS, Sewing S, Wang Y, Weichert A, Zaliani A, Gromada J. A novel glucokinase activator modulates pancreatic islet and hepatocyte function. Endocrinology, 2005; 146(9):3696-701.

Ericsson H, Sjoberg F, Heijer M, Dorani H, Johansson $\mathrm{P}$, Wollbratt M, Norjavaara E. The glucokinase activator AZD6370 decreases fasting and postprandial glucose in type 2 diabetes mellitus patients with effects influenced by dosing regimen and food. Diabetes Res Clin Pract, 2012; 98:436-44.

Futamura M, Hosaka H, Kadotani A, Shimazaki H, Sasaki K, Ohyama S, Nishimura T, Eiki J, Nagata Y. An allosteric activator of glucokinase impairs the interaction of glucokinase and glucokinase regulatory protein and regulates glucose metabolism. J Biol Chem, 2006; 281:37668-74. 
Grewal AS, Beniwal M, Pandita D, Sekhon BS, Lather M. Recent updates on peroxisome proliferator-activated receptor $\delta$ agonists for the treatment of metabolic syndrome. Med Chem, 2016a; 12:03-21.

Grewal AS, Bhardwaj S, Pandita D, Lather V, Sekhon BS. Updates on aldose reductase inhibitors for management of diabetic complications and non-diabetic diseases. Mini Rev Med Chem, 2016b; 16(2):120-62.

Grewal AS, Dua, JS, Prasad DN, Kharb R, Lather V. Design, synthesis and evaluation of novel 3,5-disubstituted benzamide derivatives as allosteric glucokinase activators. BMC Chem, 2019a; 13:2.

Grewal AS, Kharb R, Dua JS, Lather V. Molecular docking assessment of N-heteroaryl substituted benzamide derivatives as glucokinase activators. Asian J Pharm Pharmacol, 2019b; 5(1):129-36.

Grewal AS, Kharb R, Prasad DN, Dua JS, Lather V. N-Pyridin2-yl benzamide analogues as allosteric activators of glucokinase: design, synthesis, in vitro, in silico and in vivo evaluation. Chem Biol Drug Des, 2019c; 93:364-72.

Grewal AS, Lather V, Pandita D, Bhayana G. Synthesis, docking and biological evaluation of phenylacetic acid and trifluoromethylphenyl substituted benzamide derivatives as potential PPAR $\delta$ agonists. Lett Drug Des Discov, 2017; 14:1239-51.

Grewal AS, Sekhon BS, Lather V. Recent updates on glucokinase activators for the treatment of type 2 diabetes mellitus. Mini Rev Med Chem, 2014; 14:585-602.

Kohei K. Pathophysiology of type 2 diabetes and its treatment policy. Japan Med Assoc J, 2010; 53:41-6.

Lagorce D, Bouslama L, Becot J, Miteva MA, Villoutreix BO. FAF-Drugs4: free ADME-tox filtering computations for chemical biology and early stages drug discovery. Bioinformatics, 2017; 33:3658-60.

Lei L, Liu Q, Liu S, Huan Y, Sun S, Chen Z, Li L, Feng Z, Li Y, Shen Z. Antidiabetic potential of a novel dual-target activator of glucokinase and peroxisome proliferator activated receptor- $\gamma$. Metab Clin Exp, 2015; 64(10):1250-61.

Matschinsky FM, Zelent B, Doliba N, Li C, Vanderkooi JM, Naji A, Sarabu R, Grimsby J. Glucokinase activators for diabetes therapy. Diabetes Care, 2011; 34:S236-43.

McKerrecher D, Steven A. Design and development of the glucokinase activator AZD1656. In: Abdel-Magid AF, Pesti JA, Vaidyanathan R (eds.). Complete accounts of integrated drug discovery and development: recent examples from the pharmaceutical industry. Washington, DC: American Chemical Society, pp 185-220, 2018.

Miteva M, Guyon F, Tufféry P. Frog2: efficient 3D conformation ensemble generator for small compounds. Nucl Acids Res, 2010; 38: W622-7.

Miteva M, Violas S, Montes M, Gomez D, Tuffery P, Villoutreix B. FAF-drugs: free ADME/Tox filtering of compound collections. Nucl Acids Res, 2006; 34:W738-44.

Morris GM, Huey R, Lindstrom W, Sanner MF, Belew RK, Goodsell DS, Olson AJ. AutoDock4 and AutoDockTools4: automated docking with selective receptor flexiblity. J Comput Chem, 2009; 16: 2785-91.

Olokoba AB, Obateru OA, Olokoba LB. Type 2 diabetes mellitus: a review of current trends. Oman Med J, 2012; 27:269-73.

Pal M. Medicinal chemistry approaches for glucokinase activation to treat type 2 diabetes. Curr Med Chem, 2009a; 16(29):3858-74.

Pal M. Recent advances in glucokinase activators for the treatment of type 2 diabetes. Drug Discov Today, 2009b; 14:784-92.
Park K, Lee BM, Hyun KH, Lee DH, Choi HH, Kim H, Chong W, Kim KB, Nam SY. Discovery of 3-(4-methanesulfonylphenoxy)-N-[1(2-methoxy-ethoxymethyl)-1H-pyrazol-3-yl]-5-(3-methylpyridin-2-yl)benzamide as a novel glucokinase activator (GKA) for the treatment of type 2 diabetes mellitus. Bioorg Med Chem, 2014; 22(7):2280-93.

Park K, Lee BM, Kim YH, Han T, Yi W, Lee DH, Choi HH, Chong W, Lee CH. Discovery of a novel phenylethyl benzamide glucokinase activator for the treatment of type 2 diabetes mellitus. Bioorg Med Chem Lett, 2013; 23(2):537-42.

Perseghin G. Exploring the in vivo mechanisms of action of glucokinase activators in type 2 diabetes. J Clin Endocrinol Metab, 2010; 95(11):4871-3.

Pike KG, Allen JV, Caulkett PWR, Clarke DS, Donald CS, Fenwick ML, Johnson KM, Johnstone C, McKerrecher D, Rayner JW, Walker RP, Wilson I. Design of a potent, soluble glucokinase activator with increased pharmacokinetic half-life. Bioorg Med Chem Lett, 2011; 21(11):3467-70.

Pires DE, Blundell TL, Ascher DB. pkCSM: Predicting smallmolecule pharmacokinetic and toxicity properties using graph-based signatures. J Med Chem, 2015; 58(9):4066-72.

Pires DE, Kaminskas LM, Ascher DB. Prediction and optimization of pharmacokinetic and toxicity properties of the ligand. Methods Mol Biol, 2018; 1762:271-84.

Rathee D, Grewal AS, Dureja H, Lather V. Enzymatic inhibitory activity of iridoid glycosides from Picrorrhiza kurroa against matrix metalloproteinases: correlating in vitro targeted screening and docking. Comput Biol Chem, 2019; 78:28-36.

Salgueiro A, Folmer V, da Rosa H, Costa M, Boligon A, Paula F, Roos D, Puntel G. In vitro and in silico antioxidant and toxicological activities of achyrocline satureioides. J Ethnopharmacol, 2016; 194:6-14.

Singh R, Lather V, Pandita D, Judge V, Arumugam KN, Grewal AS. Synthesis, docking and antidiabetic activity of some newer benzamide derivatives as potential glucokinase activators. Lett Drug Des Discov, 2017; $14: 540-53$.

Sjostrand M, Ericsson H, Hartford M, Norjavaara E, Eriksson JW. Pharmacodynamic effects of the oral glucokinase activator AZD6370 after single doses in healthy volunteers assessed with euglycaemic clamp. Diabetes Obes Metab, 2013; 15(1):35-41.

Trott O, Olson AJ. AutoDock Vina: improving the speed and accuracy of docking with a new scoring function, efficient optimization and multithreading. J Comput Chem, 2010; 31:455-61.

Wang Z, Shi X, Zhang H, Yu L, Cheng Y, Zhang H, Zhang H, Zhou J, Chen J, Shen X, Duan W. Discovery of cycloalkyl-fused N-Thiazol2-yl-benzamides as tissue non-specific glucokinase activators: design, synthesis, and biological evaluation. Eur J Med Chem, 2017; 139:128-52.

\section{How to cite this article:}

Arora S, Grewal AS, Sharma N, Arora K, Dhalio E, Singh S. Design, synthesis, and evaluation of some novel N-benzothiazol-2-yl benzamide derivatives as allosteric activators of human glucokinase. J Appl Pharm Sci, 2021; 11 (Supp 1):038-047. 